\title{
The Extent of Accounting Ethics Education for Bachelor Students in Jordanian Universities
}

\author{
Belal Abu Anzeh \\ Department of Accounting, Applied Science Private University \\ P.O.Box 166, Amman (11931), Jordan \\ Tel. 96-26-560-999-1558Ｅ-mail: belalmslh@hotmail.com
}

Suzan Abed (Corresponding author)

Department of Accounting, Applied Science Private University

P.O.Box 166, Amman (11931), Jordan

Tel. 96-26-560-999-1558Ｅ-mail: s_abed@asu.edu.jo

Received: July 10, 2014 Accepted: October 14, 2014 Published: February 1, 2015

doi:10.5296/jmr.v7i2.6957 URL: http://dx.doi.org/10.5296/jmr.v7i2.6957

\begin{abstract}
This study aims to investigate the extent of ethics education for the undergraduate degree in accounting at public and private Jordanian Universities. A thematic content analysis methodology is conducted to interpret the collected Forty-Four syllabi for four courses offered in the universities which represent the sample of the study. These courses are Auditing, Islamic Accounting, Accounting Theory and International Financial Reporting Standards (IFRS) that given in the year 2013.

The results of the study show significant existence of ethics coverage into the undergraduate accounting curriculum specially in "auditing" course as a module of the study across Jordanian Universities. The study recommends Business Faculties in Jordan to encourage extracurricular activities orientations for further support of ethics integration through designing the accounting curriculum in professional way to prepare students to their future career.
\end{abstract}

Keywords: Accounting Curriculum, Accounting Ethics Education, Accounting Profession, Jordanian Universities. 


\section{Introduction}

The financial collapses of business pioneers such as Enron, WorldCom, Sunbeam, AIG, Tyco and HealthSouth raised critical question to ethics teaching of the involved auditors and accountants (Jennings, 2004). Ethics education in accounting should endeavor to humanize accounting students, that it should generate a sense of moral commitment towards society. In developed countries, the accounting ethics education have been argued deeply and widely for many years ago like time shortage, lack of academics' background and material, curriculum standardization (McPhail, 2001).

Some universities in developed countries have stressed, that business faculties should include accounting ethics courses in their curriculum. Recently, in the United States, the style of business education has become more serious, because of blowing up of the economic bubble in USA and discovery of misconduct, unethical behavior of senior managers and business illegal practices (Emiliani, 2004).

Treadway Commission and Bedford Committee both asked for a larger emphasis on and inclusion of ethics in accounting and business courses. The American Accounting Association (AAA) obtained the attention of business schools by stating the importance of including ethics in accounting curriculum (AAA, 1986). The Association to Advanced Collegiate Schools of Business (AACSB) stressed on including ethics in curriculum. According to the International Education Standard (IES 4), education forces need to treat themselves with ethical issues in a participative and positive way such as recognizing connections between ethical behavior and corporate failure and fraud (Calyurt, 2007).

In 1992, International Federation of Accounting (IFAC) declared the education manual: Ethics for accountants, Education Challenges and Practical Application. The recommendation of the manual that accounting ethics should take place in the curricula, and the student should be motivated to behave ethically. After that, IFAC has released the researches' results about accounting ethics education around the world, the findings stated that there was positive feedback related to the lack and scope of ethics education for accountants. There is a pervasive belief that ethics education is important to confirm coverage in the range of ethical issues which faced accountants in business firms, non-profit units and the government (IFAC, 2006).

AASCB has published a one hour obligatory ethics course in business faculties, but more than 150 professors sent a written request to AACSB reporting that a one hour obligatory course is not enough, and a four hours course coverage is integrated into each of the core course (Swanson, 2003).

The business environment is passing deep changes, pushed by powerful demographic shifts, global economic pressures and emerging technologies (AACSB, 2013). Meanwhile, society is incrementally demanding that firms become more accountable for their conducts, display a greater sense of social liability, and adopt more sustainable practices. These trends transmit a strong massage that what business wants today is much different from what it was wanted yesterday or will be wanted tomorrow, the same factors affecting business also are varying in 
higher education. In today's increasingly functional environment, universities and accounting academic departments must respond to the business environment's changing needs by giving relevant skills and knowledge to the societies they serve (AACSB, 2013). The researchers have called for the enhancement of accounting education with ethics teaching as an approach to develop the ethical decision-making and behavior of accountants (McPhail, 2001).

The failures of WorldCom, Tyco, and Enron engendered to existing concerns about unethical actions, and shaped a common concern about the financial picture distortions. In addition to other documented cases of fraud for many years ago, public confidence in the accounting career might be decreased. In the academic society, there was a strong demand for increases in ethical education and intensive discussions in the classroom, which considered a meaningful endeavor to state the effect of accounting ethics education on the ethical decision-making of accounting students and practitioners (Adkins \& Radtke, 2004).

Accounting Ethics Education equals the opportunity cost of the billions dollars losses, occurred when irresponsible unethical acts were perpetrated through the global financial crisis, of the biggest business leaders corporations around the world. The message is obvious that character building of accountant is also a deep and heavy agenda in accounting education curriculum, a basic part from the imparting of technical knowledge and skills. Today, universities as an academic center of knowledge acquisition and researches are invited strongly, to devote efforts for creating practical solutions in regaining the public trust of accounting profession reputation.

A massive responsibility places on the shoulders of education system. Extracurricular activities, curriculum design, invitation of successive professionals to universities are significant assistances in focusing the ethical awareness of accounting students. Also instructors as a part of education system, have a considerable influence on a generation's ethical awareness development across the education process. In addition to providing technical science they are potential to handle social matters and behavioral aspects. Educators are major references for today's students but tomorrow's accountants or managers in making decision what is ethical or unethical. As same as educators, families are cornerstones of a society which essentially shape generation's personality and character. The main objective of the study is to examine the extent and the content of accounting ethics education for undergraduate level in alternative module particularly auditing, accounting theory, IFRS, and Islamic accounting courses in accounting departments of both public and private Jordanian universities. The current study tries to explore the position of accounting ethics education in the curriculum of undergraduate level and the required prerequisite courses for the selected modules. Bampton and Maclagan (2005) reported that the question of "what place should ethics have in the curriculum?" is one of the initial matters regarding accounting ethics education, and having much debate on the subject in scholarly publications. The current study tries to identify which course has the highest topics of ethics.

The rest of this paper is organized as follows: Section 2 develops the theoretical framework of the study and reviews previous studies. Section 3 describes the research design. Section 4 presents the results of the study. Section 5 concludes, provides implications and 
suggests line for further research.

\section{Theoretical Framework and Literature Review}

Accounting professionals can perform their jobs in many different fields including auditing, taxation, managerial accounting, financial planning, consulting and bookkeeping (Armstrong, 2002). In each of these areas, financial statements must be applicable and presented adequately to facilitate rational decision-making in economic systems. Economic systems are therefore sustained founded on the accurate reports of the financial value of traded entities, and these essential reports are prepared by accountants. Accounting as a career is a technique as well as an art (Armstrong, 2002). Accounting professionals usually face a number of different situations requiring significant ethical judgments. They themselves recognize that there are a lot of available opportunities in their work to engage in immoral behaviors to acquire some personal benefits (Mele, 2005). Any unethical behavior in accounting will somehow lead to a failure in economic systems. As a result, various bodies attempt to sketch the map of accounting ethics to guide accounting professionals in an ethical method when they face ethical judgment problems (Ahadiat \& Mackie, 1993; Armstrong, 2002; Mele, 2005). The accounting ethics literature indicates that the scope of studies on accounting ethics extents from auditor independence to the morality of capital markets (McPhail, 2001).

The accounting industry was under much critical focusing between 1999 and 2004. The cause of the focusing was the scandals and vanishing of many important firms once respected for their business success. The financial reporting of these huge companies placed the accounting industry in a position of distrust with the public (Brackner, 1993). One of the major challenges that faced the accounting industry is to re-obtain the public's trust and to reinforce the standards and code of ethics the industry has had in place for one century ago. Over the past 100 years, the AICPA has treated with expectations and challenges presented by members, customers, investors, regulatory bodies, and users of financial statements by changing the code of ethics with the times (Edwards \& Shildneck, 1987).

The accounting profession has been able to adopt the many changes in the profession by engendering a solid foundation of a code of ethics that will raise its reputation for integrity and service to the public. In addition, the profession's leaders appeal to rely on education and moral development to furnish the moral structure for accountants' basic character (Chilton, 1992). The AICPA has installed additional standards attached to ethics and ethical education. The standards became a basic requirement for the CPA exam candidate to have a minimum of 5 years of accounting education, and CPAs not in public practice need to have continuing education in the field of ethics. The accounting profession is slowly approaching to re-obtain public trust and recognition (Misiewicz, 2007).

Despite the noticed progress in creating a professional code of ethics for accounting profession, but there are individuals who work away from the standards of industry and the code of ethics which exists the public distrust in accounting professions (Carlino, 2006). Current trends of financial reporting are moving toward faster steps with a more complicated substance and have a very low degree of tolerance for financial error. To bridge the gaps in accounting education process, accounting educators seek to revise and evaluate the 
accounting curriculum offered to future professional accountants (Cohen \& Pant, 1989). Generally, the accounting education has allocated little attention to ethical issues (Armstrong, 1993). With whole previous scandals of financial reporting process, it is clear evident that the time has reached to enter ethical studies as a core requirement to the accounting curriculum, which will assist close the gaps in ethical behavior and assess the challenges and changes of the accounting profession (Elias, 2004). Many gaps in ethical behavior take place within the accounting profession, which may be due to insufficient concerns to ethical issues within the accounting curriculum (England, 1998). Through case studies analysis of various ethical dilemmas, accounting students experience previous ethical decisions by corporate managers, leaders, and accounting firms as well as develop an ethical awareness of how these decisions affect the accounting profession (Armstrong, 1993).

As the AICPA appeals in developing its codes and standards, the organization needs to assess the expectations of the public and the ethical conducts of its members continually. It is obvious that the American accounting profession has shaped a distinguished transformation over the 20th century and will go-ahead to acknowledge the need for reform, but without developing in accounting education and curriculum, the process for varying the code may be a slowly evolving.

Nowaday what we know about business ethics that it was not indeed taught as a portion of any an official business curriculum until the1970s. Hoffman and Moor (1982) concluded that 322 of the 386 accounting ethics courses they analyzed got in the curricula after 1973. May be the reason accounting ethics is widely a post-1973 phenomena, is because societies were more homogeneous in their ethical makeup and beliefs. Perhaps a larger ethical consensus intended at that period and the perceptions concerning accounting ethics did not need to be taught because they were already comprehend. The ethical training of youth has classically been a role of family and schools. But the traditional family has deteriorated to low level in performing the role in shaping the ethical structure of youth (Carruth \& Carruth, 1991). Since the first undergraduate business schools started to see the light in the late $1800 \mathrm{~s}$, the amount of emphasis on both trends of morality and ethics has diversified. The earliest business school schedule, which grew out of traditional liberal backgrounds, stressed on educating the core person and typically included courses in ethical philosophy in their curricula. These courses were mostly required as a capstone course at the end of a students' program and they were often directed by the school's Chairman (Pamental, 1988). But over the years, the confirmations on ethical concepts and ethical decision making began to minimize as the pressure to include more specific accounting professional content maximized. Not only was time condition or space in syllabi a factor in the decision to minimize the emphasis on moral philosophy, but business faculty also started to ask the question whether they were really qualified to teach these kinds of values oriented courses since majority of them did not have enough training in ethics and moral development (Oddo, 1997; Acevado, 2001; Sims, 2004).

Also, at that era, courses in ethical philosophy started to be involved into newly created philosophy departments and these courses no longer held the same central position in the undergraduate degree generic requirements (Parmental, 1989). In addition, with faculty and students becoming more diverse in their backgrounds, nationalities, religious beliefs, ethnic 
structure, and worldviews, the question of whose values should be taught started to be existed on the land escape. While business faculties and universities extended to debate the role of ethical philosophy in accounting education, the pragmatic need to have accounting ethics educated in some format began to expand as evidenced by several financial-business scandals.

Members of (AACSB) started to debate whether a values or ethics requirement should be a portion of accreditation standards. Their debate synchronized with two American studies on the curriculum which were performed by the Carnegie Foundation (Pierson, 1959) and the Ford Foundation (Gordon \& Howell, 1959). These two early studies resulted to several remarkably similar conclusions including the fact that the representative business faculty curricula did not include a sufficient emphasis on values oriented courses. Both researches recommended adopting a business/social plan course which would be values focused. This new required course would expand beyond the business law courses which were considered to be too narrow in their scope (Collins \& Wartick, 1995). The Carnegie study predicted that the accountant as a business job would become more complicated and would require more perception of and sufficient sensitivity to the economic, political, and several social aspects of environment. The Carnegie study concluded that, in the visible future, accounting students and business faculty should contend seriously to develop a personal philosophy and ethical structure for business life and decision making processes (Pamental, 1989). As a result of the financial scandals of the 1960s and all intensive efforts produced by the Carnegie Foundation study, the Ford Foundation study, and the debate through the AACSB focused on values-oriented courses, changes were actually made in the AACSB recommended business colleges curriculum. In 1967, the AACSB underwent to the pressure and recognized the need to teach ethical values in the curriculum by stating that business faculty and students needed to consider how social and political influences affect organizations (AACSB, 1967). While the requirement was not specified and accurate, it did open the gate to an ethics requirement which became a portion of the AACSB accreditation standards in 1976 (AACSB, 1976). However, in the process of developing and applying their ethics requirement, the AACSB was not specific as to how the requirement should be done in the undergraduate curriculum by educators, stated only that the topic must be addressed (McMahon, 1999). This permitted the AACSB accredited and accreditation seeking universities to implement the ethics training requirement in a variety of approaches.

Despite its significance, the title of ethics educations in the faculty curriculum is somehow problematic and controversial issue (Brinkman \& Sims, 2001). Some universities have required all accounting degree seeking students to pass an accounting ethics course as a part of their core curriculum (Sims \& Sims, 1991). In contrast, other universities have endeavored to enter the accounting ethics content within their whole accounting core curriculum (Buchholz, 1979; Paine, 1988; Shannon \& Berl, 1997). Some universities have applied both, requiring a core accounting ethics class while implementing those concepts within the remainder of their accounting core classes (Piper et al, 1993).

According to Acevado, 2001 accounting Ethics course is interesting and/or beneficial, the fact the ethics course is being taught to adults (students over 18 years of age) means it is being 
taught to human whose moral frameworks have already been shaped and are not likely to change much, if at all. For example, Carruth and Carruth (1991) found that $72 \%$ of the faculty students surveyed and ensured that students' ethical/moral principles have been established, and are not likely to be changed, but they also stated that education, including ethics training, may provide the soundest basis for the outstanding development and improvement of student's character. Furthermore, there are two limitations for accounting ethics education: Firstly, the majority of teachers have no ethics training formally. Secondly, most ethics teaching is integrated into the current accounting course which is exposed to the will of the teacher to devote the requisite time to ethical cases (Gunz and McCutcheon, 1998). Borkowski and Ugras (1998) reported that students should learn early in academic programs that ethical behavior is valued seriously by the business environment, and this belief should be integrated into the curricula the reason why students can demonstrate more ethical behaviors and attitudes. But if the recent financial scandals are any indication, apparently the integrated method to ethics education has not been often successful, or at least, it did not prevent the recent moral scandals.

Other researchers and educationists have suggested a stand-alone course in ethics education can create a better ethics foundation which could be utilized for a wide range of future ethical applications in work environment (Sims \&Sims, 1991).

In light of these criticisms, some researchers believe that the best method to treat with ethics training in the undergraduate curriculum is to embrace both/and method. This can best be made by requiring a core Accounting Ethics class, which would support the depth of analysis, in parallel line with integrating ethics education into the overall accounting curricula, reaching to demonstrate its relevance across courses. Acevado (2001) stressed that both/and approach would likely provide more strict and comprehensive coverage and in-context reinforcement within the undergraduate curricula. Several researches suggest the both/and approach is preferable (Duska, 1991; Sims \& Sims, 1991; Glenn, 1992; Cooke, 1992; Piper et al., 1993). Ethics teaching in higher education have several objectives. Callahan (1980) identified five objectives for ethics education implicating: stimulating the moral imagination, understand moral issues, eliciting a sense of moral obligation, developing analytical skills, and tolerating and reducing disagreement and confusion. Powers and Vogel (1980) added a sixth objective for ethics courses: integrating managerial and moral competence. Beyond those six objectives, the student can receive three different and featured methods: context-oriented, process-oriented, and content-oriented.

In closing, Kohlberg of cognitive moral development theory has shaped the theoretical basis for most researches and papers in accounting ethics education and related issues (Jones et al., 2003). According to Kohlberg's theory, ethical development is the level of moral reasoning an individual used to advocate his or her position when a moral conflict occurred. It is related to the consideration (solid base) of what should ideally be conducted to resolve a particular ethical dilemma. Because of its popularity, universality, and applicability in the EEF of IES4 (professional values, ethics and attitudes) which released by IFAC, this research takes Kohlberg's theory as a theoretical example for interpreting accounting ethics education in accounting curriculum designing and potential reflections on the accounting students 
behavior.

\section{Research Methodology}

\subsection{Research Instrument}

The main purpose of this research is to investigate, how the universities prepare graduates for the ethical challenges of the accounting profession, through the integration of ethics content in their accounting courses. The study conducts a qualitative content analysis method to interpret the collected syllabi, representing four centric accounting modules (Auditing, IFRS, Accounting Theory, and Islamic Accounting), that offered by the University, the Faculty of Business and the Accounting Department. It does so in order to determine the extent to which Accounting Ethics Education internalizes into Jordanian undergraduate universities accounting degrees.

Therefore, it was found that in order to consist with the previous rationalization, the current study adopts content analysis approach to analyze the accounting ethics education as a prescribed methodology. Also the utilizing of the qualitative content analysis techniques avoids the pitfall of quantitative analysis techniques concerning accounting ethics as mentioned before (Dyball et al, 2012).

Both Fleming (1996) and Harmon et al. (2006) interpreted thematically the content of syllabi in different educational areas in order to conclude their own significant contributions in literatures. The present study approaches a qualitative content analysis method to investigate the expected themes that includes the real coverage of accounting ethics education into collected 44 undergraduate accounting syllabi which presents a sample of the study.

In the academic disciplines, researchers consider syllabus as the "compass" (Royse, 2001) or "map" (Albers, 2003) of academic study. Certainly, these two cited words reflect the significance of the syllabus as a document or device achieves the variety of functions such as, providing plenty of important observations about a specific education program, that enable the researchers to conduct a thematic analytical approach across the researches processing.

\subsection{Data Collection Methods}

Jordan is an Arabic country which internationally classified as a developing country, and Islam is the religion of the country formally, with an important existence of Christian citizens through demographic environment, which means, that moral values -as a research area-are derived from religious background and Arab culture legacy. Since the first public university-University of Jordan- had been established in1962, the higher education system grew rapidly in launching other universities to be now totally 29 consisted of 10 as public and 19 as private universities. 25 universities offer undergraduates accounting degree within wholly academic programs. The current study focuses only upon Accounting Ethics Education within undergraduate accounting degree, whether taught as standalone module or as integrated module into an Auditing, IFRS, Accounting Theory and Islamic Accounting. Therefore, the syllabi of auditing, IFRS, accounting theory and Islamic accounting modules were reviewed and analyzed to explore the extent and content of Accounting Ethics 
Education.

In order to achieve the study objective, all the 25 universities that taught accounting program web-sites were checked up in order to download the submitted syllabi directly. As a result, just two universities were optioned the required download. An initial request for syllabi was forwarded to the remaining 23 universities with an accounting department. All member staff listed in accounting departments' Webs and having teaching interests in auditing, IFRS, accounting theory and Islamic accounting were forwarded requests. A total of 17 outlines were received (6 auditing, 4 IFRS, 4 accounting theory and 3 Islamic accounting). A second request was sent by e-mail approximately 20 days later. This results in getting extra 12 outlines (5 auditing, 2 IFRS, 3 accounting theory and 2 Islamic accounting). To enhance further the scope of data, the final phase of data collection was conducted by visiting the non-responded universities toward e-mail requests. This process generated another additional 15 outlines (4 auditing, 5 IFRS, 3 accounting theory and 3 Islamic accounting).

In summary, the data collection process resulted in a final sample of 44 outlines (15 auditing, 11 IFRS, 10 accounting theory and 8 Islamic accounting). Table 1 shows sample of the study.

Table1. Sample of the Study

\begin{tabular}{|l|l|}
\hline Courses Modules & Collected Syllabi(n) \\
\hline Auditing & 15 \\
\hline Accounting Theory & 10 \\
\hline IFRS & 11 \\
\hline Islamic Accounting & 8 \\
\hline Total of Sample $=\mathrm{n}$ & 44 \\
\hline
\end{tabular}

Some significant differences emerge through modules of the current sample due to: first, the degree of responses to requests from accounting department to another in various universities, second, the non-availability of outlines in some universities, and third, the Islamic accounting module is not listed as a compulsory course into accounting department catalog because it might require an enough religious background beside the academic qualifications of staff member.

Descriptive analysis is used to analyze the above dimensions based on the expected themes in order to derive the findings through the next section of the study. A sample of forty four syllabuses was collected, reviewed and examined in order to investigate and explore the ethics themes by the content analysis methodology in four dimensions existed within the outlines. These dimensions are: Course Level, Course Objectives, Course Description, and Course Content will be thematically analyzed in the next sections of this chapter.

\section{Finding and Results}

\subsection{Ethics Education vs. Course Level}

One important issue regarding the delivery of accounting ethics education is whether the courses of positioned ethical content should be offered within the undergraduate or graduate level. Table 2 shows that the majority (77\%) of studied universities offer the courses that 
include ethics material through exclusively at the graduate level and/or advanced years of accounting under graduate curriculum. Therefore, these universities required initially a prerequisite course before having auditing, accounting theory, IFRS and Islamic accounting classes. The remaining $(23 \%)$ of sampled courses syllabi do not mention whether a prerequisite course is required or not.

Table 2. Ethics Education-Course Level

\begin{tabular}{|l|l|l|l|}
\hline Courses Modules & Collected Syllabi(n) & Prerequisite Condition & Percentage \\
\hline Auditing & 15 & 12 & $80 \%$ \\
\hline Accounting Theory & 10 & 7 & $70 \%$ \\
\hline IFRS & 11 & 7 & $63.6 \%$ \\
\hline Islamic Accounting & 8 & 5 & $62.5 \%$ \\
\hline Total of Sample $=\mathrm{n}$ & 44 & 34 & $77.3 \%$ \\
\hline
\end{tabular}

In some cases, the senior level undergraduate courses have a double listing as graduate courses and may meet either undergraduate or graduate degree requirements. This appears to suggest an attempt to confirm that accounting students should have a sufficient understanding of the various accounting concepts covered at the undergraduate level before they are given the opportunity to receive the advanced courses that include accounting ethics education. It may also bring to light that most undergraduate degree programs are containing of courses considered necessary and that locating a place for new titles is more preferable at the graduate level to avoid displacing undergraduate curriculum content.

The ethics education modules are quite varying in their specifications of prerequisites, such as: (1) introductory accounting, (2) intermediate accounting, (3) business corporate accounting, (4) accounting theory, (5) International Accounting Standards (IAS). Those prerequisites may vary from university to another in accordance to adherent with their own accounting education strategies and/or academic visions. However, these prerequisites are explored in the majority of the studied syllabi and are not systemized in any specified order but reflect the wide range of accounting perceptions, concepts, skills, and motivations that accounting students are supposed to bring to the accounting class.

\subsection{Ethics Education vs. Course Objective}

Accordingly, this study reviewed 44 syllabi for alternative modules by preparing a master list includes ethical themes into learning objectives' part of each syllabus and the findings of the process most commonly focuses upon providing accounting students with an understanding of the following ethical themes in auditing modules: (1) Nature of Ethics, (2) Ethical Codes of Professional Conduct, (3) Auditor Responsibilities, (4) Auditor Liabilities (legal, criminal, honorary), and (5) Fraud and related issues. The results reflect that universities' commitment in the orientation of accounting student cognitive structure, by the integration of ethical moulds and concepts that associated initially with auditor conduct in accounting undergraduate curriculum, which is consistent with Kohlberg Moral Development Theory and the influence of designing accounting curriculum on the student maturity of moral reasoning in ethical decision making when ethical dilemmas could be occurred in future work 
life. Table 3 shows the content of accounting ethics in the learning objectives of the syllabi of the selected courses.

Table 3. Ethics Education-Learning Objectives

\begin{tabular}{|l|l|l|}
\hline Learning Objective Themes & Freq & $\begin{array}{l}\% \text { of separate } \\
\text { Module }\end{array}$ \\
\hline $\begin{array}{l}\text { 1. Provide a general understanding of Ethical values, nature } \\
\text { concepts and need in auditing }\end{array}$ & 4 & $26.7 \%$ \\
\hline $\begin{array}{l}\text { 2. Provide students with an understanding of Ethical codes of } \\
\text { professional conducts }\end{array}$ & 13 & $86.7 \%$ \\
\hline $\begin{array}{l}\text { 3. Provide an explaining of auditors responsibilities to clients and } \\
\text { stakeholders }\end{array}$ & 12 & $80 \%$ \\
\hline $\begin{array}{l}\text { 4.Provide an understanding of fraud concept, characteristics, forms, } \\
\text { and responsibilities to detect therein }\end{array}$ & 10 & $66.7 \%$ \\
\hline $\begin{array}{l}\text { 5.Provide students with perception of auditor liabilities, Legal, } \\
\text { Criminal, Honorary }\end{array}$ & 11 & $73.3 \%$ \\
\hline $\begin{array}{l}\text { 6.Provide a definition of Ethical values as a base of financial } \\
\text { transactions in Islamic Shari'ah }\end{array}$ & 5 & $62.5 \%$ \\
\hline $\begin{array}{l}\text { 7.Provide a definition of Islamic accounting system through the } \\
\text { conceptual-ethical framework of Islamic Shari'ah }\end{array}$ & 6 & $75 \%$ \\
\hline $\begin{array}{l}\text { 8.Provide a vision of theoretical foundation of accounting theory, } \\
\text { Ethical, behavioral, and social approaches }\end{array}$ & 4 & $40 \%$ \\
\hline $\begin{array}{l}\text { 9.Provide an explaining of unethical accounting practices, } \\
\text { aggressive accounting, earning management, creative accounting }\end{array}$ & 3 & $30 \%$ \\
\hline $\begin{array}{l}\text { 10.Provide a concept of Ethical challenges in decision-making of } \\
\text { practicing IFRS }\end{array}$ & 3 & $27.3 \%$ \\
\hline
\end{tabular}

Note: Themes 1-5 for Auditing, 6-7 Islamic Accounting, 8-9 Accounting Theory, 10 IFRS

As it is appeared in the above table, excluding the first theme (Nature of Ethics) in 4 audit modules with a percent of $(26.7 \%)$, the other diverse four themes vary from $(66.7 \%)$ up to $(86.7 \%)$ of auditing syllabi with high likelihood of including several themes.

Islamic Accounting opens the horizons to create an integrative model of overlapping a Non-Western culture represented in an Islamic Intellectual background, with ethics education through accounting undergraduate curriculum which represents a new opportunity of using the flexible boarders of IES4 in accommodating various cultures and religious backgrounds. After reviewing the 8 Islamic Accounting syllabi, it was familiar to derive the following dual learning objectives themes that provide definitions of: (1) Ethical Values as a base of financial transactions in Islamic economy, and (2) Islamic accounting system through the conceptual framework of Islamic canon. In Islamic Accounting modules, themes were quite commonly found in 5, 6 syllabi respectively of the 8 modules, which mean that in some cases, the two learning objectives were already available in more than one syllabus. Also content 
analysis techniques are used to interpret the implications through ethical themes of learning goals in accounting undergraduate curriculum, specially Accounting Theory and IFRS modules. In these modules, Ethical, Behavioral and Social theories as approaches to conceptual framework of the accounting theory could be considered as a theme, whilst the Creative, Aggressive Accountings and Earning Managements practices are included in the another one. Learning objectives of IFRS courses occupied as similar as Accounting Theory fewer frequency of syllabi than both Audits and Islamic Accounting modules. Perhaps the fewer-frequency courses' (IFRS \& Accounting Theory) educators recognizes that an ethical content should be given and/or aimed in other courses such as auditing or Islamic Accounting classes. In addition to differences in the cognitive-materials nature of each oriented curriculum in comparison with others, and the crowded syllabi by accounting concepts, techniques, and several related subjects.

\subsection{The extent of accounting ethics education for undergraduate level}

The extent of accounting ethics education for undergraduate students associated directly with the following two types of requirements:

Core Cognitive Requirements: which summarized in the fact that universities' academic strategies prefer that undergraduate accounting student should own an intellectual-knowledge background supported with theoretical and practical accounting techniques that should be provided in other accounting courses.

Time Passage Requirement: which relates to that the processing of creating-responsible professional accountant and auditor, equipped with ethical decision making and critical thinking-abilities is demanding a long time stages and phases to get ready for comprehending such a different complicated type and/or nature of knowledge acquisition.

\subsubsection{Ethics Education vs. Course Description}

"Course Description" analysis in this study assists in determining the integration of Ethics Education into accounting courses, the what and the how that Jordanian Universities appear to be supporters of ethics integration strategy. This supportive strategy is not only demonstrated by their respective mission statements and associated promotion materials, but also by the depth and breadth of the accounting courses offered, that are devoted to, or include, content specific to ethics. Table 4 illustrates course description themes through the forty four syllabi of research modules.

Table 4. Ethics Education-Course Description

\begin{tabular}{llll}
\hline Panel & Descriptions & $\begin{array}{l}\text { Frequency of } \% \text { of each } \\
\text { each module } \\
\text { module }\end{array}$ \\
A & $\begin{array}{l}\text { 1. Defining the importance of Professional } \\
\text { Ethics in auditing profession }\end{array}$ & $46.7 \%$ \\
& $\begin{array}{l}\text { 2. Providing the students with an } 13 \\
\text { understanding of the Legal Liabilities and } \\
\text { other liabilities of auditor }\end{array}$ & $86.7 \%$ \\
\hline
\end{tabular}


3. Explaining Auditor Responsibilities 12

\begin{tabular}{|c|c|c|c|}
\hline & $\begin{array}{l}\text { 3. Explaining Auditor Responsibilities } \\
\text { concepts }\end{array}$ & 12 & $80 \%$ \\
\hline & $\begin{array}{l}\text { 4. Defining Fraud Auditing, motivations, } \\
\text { forms, and treating with }\end{array}$ & 11 & $73.3 \%$ \\
\hline & $\begin{array}{l}\text { 5. Explaining and defining Types of Codes } \\
\text { of Ethical Conduct and developments across } \\
\text { profession history }\end{array}$ & 13 & $86.7 \%$ \\
\hline & $\begin{array}{l}\text { 6. Give an image of Professional and } \\
\text { personal characteristics of auditor }\end{array}$ & 6 & $40 \%$ \\
\hline & $\begin{array}{l}\text { 7. Illustrating the appointment and } \\
\text { dismissal of the auditor, conditions and } \\
\text { cases }\end{array}$ & 9 & $60 \%$ \\
\hline & $\begin{array}{l}\text { 8. Increase the students knowledge of the } \\
\text { Consequences of Ethical Breaches on } \\
\text { Auditing Profession }\end{array}$ & 5 & $33.3 \%$ \\
\hline \multirow[t]{3}{*}{$\begin{array}{l}\text { B } \\
\text { Islamic } \\
\text { Accounting }\end{array}$} & $\begin{array}{l}\text { 1. Providing an explaining of the } \\
\text { importance of Ethical Values from Islamic } \\
\text { perspective in financial transactions }\end{array}$ & 6 & $75 \%$ \\
\hline & $\begin{array}{l}\text { 2. Focusing on Ethical aspects of fund } \\
\text { concept through Moslem individual's } \\
\text { expenditure facets }\end{array}$ & 5 & $62.5 \%$ \\
\hline & $\begin{array}{l}\text { 3. Giving the concepts of Zakat and Reba } \\
\text { in Islamic perceptions and related Ethical } \\
\text { contents into the Islamic society }\end{array}$ & 6 & $75 \%$ \\
\hline \multirow[t]{3}{*}{$\begin{array}{l}\text { C } \\
\text { Accounting } \\
\text { Theory }\end{array}$} & $\begin{array}{l}\text { 1. Giving an idea about the implications of } \\
\text { immoral conducts that caused historically } \\
\text { the financial crises across the accounting } \\
\text { profession development }\end{array}$ & 3 & $30 \%$ \\
\hline & $\begin{array}{l}\text { 2. Studying the Ethical, Behavioral and } \\
\text { Social approaches to theoretical foundation } \\
\text { of accounting theory }\end{array}$ & 7 & $70 \%$ \\
\hline & $\begin{array}{l}\text { 3. Studying the intentional-unethical } \\
\text { accounting practices, aggressive accounting, } \\
\text { earning management, creative accounting } \\
\text { methods }\end{array}$ & 5 & $50 \%$ \\
\hline $\begin{array}{l}\text { D } \\
\text { IFRS }\end{array}$ & $\begin{array}{l}\text { 1. Defining the Ethical Issues of decision } \\
\text { making through the using IFRS standards } \\
\text { and Social Responsibility Reporting. }\end{array}$ & 4 & $36.4 \%$ \\
\hline
\end{tabular}

As similar as to what was done in course objectives analysis, the forty-four outlines are examined in order to explore the nature of ethics description themes into accounting courses offered. Accounting educators used two forms to express the written course descriptions: first, the contextual separate paragraph, second, the serial numbered descriptions, that require rewriting themes in listed-numbers. 


\section{Macrothink}

The results of content analysis through description dimension indicate that more of $70 \%$ audit syllabi are including the four following themes in panel A: (1) Auditor liabilities (legal, criminal, honorary), (2) Auditing responsibilities, (3) Fraud auditing, and (4) Ethical Codes of Professional Conduct. In Islamic Accounting, the themes in panel B 1, 2 and 3 yield respectively $75 \%, 62.5 \%$ and $75 \%$ of syllabi therein. As noticed in panel $\mathrm{C}$ themes 1,2 and 3 approximate $30 \%, 70 \%$ and $50 \%$ with obvious appearance of "Ethical, Behavioral and Social approaches to theoretical foundation of accounting theory" as a basic, normal related theme to Accounting Theory course. Meanwhile, the IFRS single theme of ethical issues and social responsibility of standards implementations yields $36.4 \%$ of IFRS syllabi.

\subsubsection{Ethics Education vs. Course Content}

The course ethical content of all syllabi were also examined and interpreted using the same method that used in course description and course objectives themes, as stated in Table 5. 
Table 5. Ethics Education-Course Content

\begin{tabular}{|c|c|c|c|}
\hline Panel & Topics of Course Content & Frequency & Percentage \\
\hline \multirow{18}{*}{$\begin{array}{l}\text { A } \\
\text { Auditing }\end{array}$} & 1.Kinds of errors (unintentional, intentional ) & 13 & $86.7 \%$ \\
\hline & 2.Definetion of fraud & 14 & $93.3 \%$ \\
\hline & 3.Reasons of fraud perpetration & 13 & $86.7 \%$ \\
\hline & 4.Methods of detecting the fraud & 12 & $80 \%$ \\
\hline & 5.Forms of fraud & 14 & $93.3 \%$ \\
\hline & 6.Audition responsibilities toward detecting fraud & 11 & $73.3 \%$ \\
\hline & 7.Auditing evidence sufficiency & 14 & $93.3 \%$ \\
\hline & 8.Personal characteristics of auditor & 10 & $66.7 \%$ \\
\hline & 9.Auditor legal liability & 14 & $93.3 \%$ \\
\hline & 10.Auditor criminal liability & 14 & $93.3 \%$ \\
\hline & 11.Auditor honorary liability & 13 & $86.7 \%$ \\
\hline & 12.Auditor appointment and dismissal & 13 & $86.7 \%$ \\
\hline & 13.Auditor rights and responsibilities & 10 & $66.7 \%$ \\
\hline & 14.Ethical codes of professional conducts concept & 14 & $93.3 \%$ \\
\hline & 15.Develpment and kinds of Ethical codes & 12 & $80 \%$ \\
\hline & $\begin{array}{l}\text { 16.Relationships between codes and regulations or } \\
\text { laws }\end{array}$ & 11 & $73.3 \%$ \\
\hline & $\begin{array}{l}\text { 17.Auditor situation \& responsibilities to internal } \\
\text { control }\end{array}$ & 10 & $66.7 \%$ \\
\hline & 18.Post-Auditing process responsibility & 9 & $60 \%$ \\
\hline \multirow{5}{*}{$\begin{array}{l}\text { B } \\
\text { Islamic } \\
\text { Accounting }\end{array}$} & 1.Ethical values in Islamic concept & 6 & $75 \%$ \\
\hline & 2.Ethics as rules of business transaction is Islam & 5 & $62.5 \%$ \\
\hline & 3.Ethical aspects in fund concept of Islam & 5 & $62.5 \%$ \\
\hline & 4.Ethical content of "Zakat" concept & 4 & $50 \%$ \\
\hline & 5."Reba"concept and its unethical implications & 4 & $50 \%$ \\
\hline \multirow{4}{*}{$\begin{array}{l}\text { C } \\
\text { Accounting } \\
\text { Theory }\end{array}$} & $\begin{array}{l}\text { 1.Financial crises in accounting profession } \\
\text { history(Enron, AIG ) }\end{array}$ & 4 & $40 \%$ \\
\hline & 2.Ethical theory in accounting theory foundation & 6 & $60 \%$ \\
\hline & $\begin{array}{l}\text { 3.Behavioral, social theories in accounting theory } \\
\text { foundation }\end{array}$ & 5 & $50 \%$ \\
\hline & $\begin{array}{lll}\text { 4.Agressive, Creative accountings, Earning } \\
\text { Management }\end{array}$ & 4 & $40 \%$ \\
\hline \multirow{2}{*}{$\begin{array}{l}\text { D } \\
\text { IFRS }\end{array}$} & 1.Unethical adaption of IFRS of decision making & 4 & $36.4 \%$ \\
\hline & $\begin{array}{l}\text { 2.Ethical concept of responsibility accounting in } \\
\text { IFRS implementation }\end{array}$ & 5 & $45.5 \%$ \\
\hline
\end{tabular}

The mainstream of themes advocates obviously through tracing process of course content topics that leads to logical results. The first result that can be drawn from Table 5 is that the increasing number of ethical content topics, in all selected modules due to, that the accounting educators execute or translate their academic descriptions to the students through 
expanding in vertically and horizontally their own intellectual material which they should be delivered actually. Therefore, the increasing number of themes appears clearly in auditing to 18, Islamic Accounting to 5, Accounting Theory to 4 and IFRS to 2 topics. The second result, is that auditing courses still being more dominant in yielding more frequency and/or percentages than the others, perhaps because that these courses are rich in ethical materials that should be given to equip the accounting students for facing the ethical challenges across their future work profession life. For examples, Table 5 panel A shows that themes number 5 , 7, 9, 10 and 14 represent $93.3 \%$ of topics taught in the selected universities. These examples mirrors the instructors' consensus to focus perfectly their academic efforts toward ethical decision making processing as a significant perception concerns critically the accounting undergraduate student in auditing class. In the sequence, the findings of Table 5 Panel B indicate that Islamic Accounting modules have been devoted to derive thematic ethical contents from religious background which is rich of moral values. The five content topics in the Islamic module yield the percentages ranged from $50 \%$ to $75 \%$ of the themes taught in the selected syllabi, while the four topics of Accounting Theory approximates $40 \%$ up to $60 \%$ of the taught themes, and the last two topics in IFRS record $36.4 \%$ and $45.5 \%$ of syllabi taught topics.

Table 6 incorporated all the thematic topics covered in the selected modules in alternative universities. Table 6 presents the descriptive values of ethics topics coverage through the study modules. The ethics topics for auditing syllabi increased over the other modules which indicate obviously the broad base of ethical concepts integration in auditing courses rather than the other modules with the percent of $62 \%$ coverage of all topics. On the other hand, this broad base presents a solid foundation to build a cognitive ethical background qualifies the accounting curriculum to promote student's ethical maturity level of moral reasoning in ethical decision making toward potential ethical dilemmas to meet further consistency with six hierarchical stages' Kohlberg Moral Development Theory which explains how individuals shape ethical behavior within various work environments. Furthermore, the percentages record superiority of auditing modules regarding ethics content compared to Islamic Accounting, Accounting Theory and IFRS courses with highest percent of $93.3 \%$ of coverage among accounting departments in the public and private Jordanian universities.

Table 6. Ethics Education Topics in Study Module

\begin{tabular}{|l|l|l|l|l|}
\hline Descriptive Value & Auditing & Islamic accounting & Accounting Theory & IFRS \\
\hline Number of themes & 18 & 5 & 4 & 2 \\
\hline Percentage of coverage & $62 \%$ & $17.2 \%$ & $13.8 \%$ & $7 \%$ \\
\hline
\end{tabular}

This result consistent with Cohen \& Pante (1989), Gunz \& McCucheon (1998), Sims (2000), Molyneaux (2004), Caliyurt \& Crowther (2006) and Gungormus \& Uyar (2013) who concluded that Auditing course has the most ethics coverage rather than the other accounting course. As similar, this study explored that ethics material is most integrated within auditing courses in comparison to Islamic Accounting, Accounting Theory and IFRS modules. The accounting ethics integration in auditing evidenced by the highest percentages of auditing 
syllabi within each of course objectives, course description and course content modules.

\section{Conclusion, Implications and Recommendations}

While ethics education has been included in at least some courses through undergraduate accounting curriculum in Jordanian universities, surprisingly, there is a one separate optional course of Business Ethics offered as a business faculty course and out of accounting department catalogs offered to marketing, economy, business-administration, management information system and accounting students, that could be described as an outlier serious attempt to enforce ethics education into business faculty multi-departments catalog, and mirror a stand-alone ethics course method.

On the other hand, the finding of this study implies straightforwardly that accounting educators in Jordanian universities adapt the ethics content integration method into undergraduate curriculum, and this could be demonstrated actually by reviewing and examining the selected courses syllabi data, and related interpreted tables that led directly to the exploration, of the extent and the real covered material of Accounting Ethics Education, which should be delivered to undergraduate accounting students. Perhaps, this adaption refers to the referenced textbooks integration method, the crowded topics course-outlines, the extra fund cost of such an additional course, and/or that the educators could be influenced by their own higher education certifications resources, styles, policies, and strategies.

Ironically, the findings implies negatively the existence of any theoretical evidence to such one of Ethics Theories (e.g. Egoism, Utilitarianism, Virtue, Deontology) in order to expand the undergraduate student perception in the critical thinking of ethical decision making while facing ethical dilemmas. These theories assist the students to shape a significant cognitive background to understand more ethical concepts, nature, psychological, behavioral, and social aspects of the human ethical conduct rather than to believe that the ethics material is districted in some topics that, need more digestive academic processing to be tackled, such as the standardized moulds of applied ethics, is sufficient to be delivered to accounting students. For example, the Ethical Code of Professional Conduct as a matter integrated within auditing curriculum, which focused basically on characteristics as a requirement of a qualified person his her career is auditing profession. The duty of ethical actions is what causes human beings to exceed animals, the reason why humans have the ability to conduct on a moral level (Duska \& Duska, 2003). By making a comparison between the two concepts in the example above, perhaps the different is obvious for accounting students to understand pedagogically ethical value as a code patterns rather than a branch of philosophical theory or a broad science of ethics.

The undoubted various spaces of ethics material through courses in the scope of the study, is an implicative matter merits more ultimate discussions. Some educationists and academicians consider the fact that "ethics can be taught", but the others do not believe in that fact by considering that moral values should be cultivated in individual character by the family role and in the early education schools. Perhaps this controversial nature of accounting ethics education reflects pedagogically, the accounting educators' performance in integrating ethics content in their classes. Which could also explain that if some accounting educators do not 
teach ethics, does not mean basically that they do not believe in the importance of moral values, in the accountant character. Finally, ethics is not only a theory or value, but a method of life and the straight lifeline of the accounting profession. Ethics education can assist undergraduate accounting students to develop precise ethical behavior and understand ethical decision making in their future accounting professionalism.

According to conclusions, a future studies could involve a study of exploring the ethics content inclusions in the most popular accounting textbooks that used as references in the undergraduate accounting degree of Jordanian universities. Another future study could be conducted to examine the level of ethics education among the higher education degrees for master and $\mathrm{PhD}$ programs in order to report the amended accounting ethics education in the Jordanian universities. Accounting educators as an effective part of the higher education system should transmit not only technical knowledge but also ethical awareness and critical thinking in ethical decision making to face ethical dilemmas, through suggested visions about accounting curriculum design. Moreover, business faculties in Jordanian universities should be encouraged to represent the IES4 whether in stand-alone course or integration through accounting courses, by confirming the importance of the extracurricular activities, faculty's mission statement, and other accessible alternatives in enhancing the ethical training process starts up by undergraduate accounting student behavior in campus to include all events across his/her student life.

\section{References}

AAA, American Accounting Association. (1986). Committee on the Future Structure, Content, and Scope of Accounting Education (The Bedford Committee),(1986) "Future accounting education: Preparing for the expanding profession. Issues in Accounting Education (Spring): 168-195.

AACSB International the Association to Advanced Collegiate Schools of Business. (2013). Eligibility Procedures and Accreditation Standards for Accounting Accreditation. United States of America. South Harbour Island

Acevado, A. (2001). Of fallacies and curricula: a case of business ethics. Teaching Business Ethics, 5(2), 157 -170. http://dx.doi.org/10.1023/A:1011493530061

Adkins, N., \& Radtke, R.R. (2004). Students' and Faculty Members' Perceptions of the Importance of Business Ethics and Accounting Ethics Education: Is There an Expectations Gap?. Journal of Business Ethics, 5(1), 279-300

Ahadiat, N., \& Mackie, J. J. (1993). Ethics education in accounting: An investigation of the importance of ethics as a factor in the recruiting decisions of public accounting firms. Journal of Accounting Education, 77(2), 243-257. http://dx.doi.org/10.1016/0748-5751(93)90005-4

Albers, C. (2003).'Using the syllabus to document the scholarship of teaching" College Teaching, 31(1), pp 60-72

American Institute of Certified Public Accountants AICPA (2006) Code of Professional Conduct of American Institute of Certified Public Accountants. Retrieved July 10, 2006, 
from http ://www. aicpa. org/about/code/index. Html

Armstrong, M. B. (1993). Ethics and professionalism in accounting education: sample Course. $\begin{array}{lllll}\text { Journal of Accounting } & \text { Education, } & 11(1),\end{array}$ http://dx.doi.org/10.1016/0748-5751(93)90019-F

Armstrong, M. B. (2002). Ethical issues in accounting” In N. E. Bowie (Ed.), The Black-well guide to business ethics (pp. 145-164). Malden, MA: Blackwell Publishers

Bampton, R., \& Maclagan, P. (2005). Why teach ethics to accounting students? A response to the skeptics" Business Ethics: A European Review, 14, 290-300. http://dx.doi.org/10.1111/j.1467-8608.2005.00410.x

Bok, D. C. (1976). Can ethics be taught? Change, 8(9), 26-30 http://dx.doi.org/10.1080/00091383.1976.10568973

Boyle, T. (2003). Design principles for authoring dynamic, reusable learning objects. Australian Journal of Educational Technology 2003, 19(1), 46-58

Borkowski, S. C., \& Ugras, Y. J. (1998). Business students and ethics: a meta-analysis". Journal of Business Ethics, 17(11), 1117-1127. http://dx.doi.org/10.1023/A:1005748725174

Brackner, J. (1993). Our ethical foundations. Management Accounting, 75(6), 61-72

Brinkman, J., \& Sims, R (2001). Stakeholder sensitive business ethics teaching. Teaching Business Ethics, 5(2), 171 -193. http://dx.doi.org/10.1023/A:1011461418842

Brooks, L. (1989). Ethical codes of conduct: Deficient in guidance for the Canadian accounting profession. Journal of Business Ethics, 8(5), 325-336

Buchholz, R. A. (1979). Business environment and public policy: A study of teaching and research in schools of business and management. Saint Louis, MO: Washington University.

Caliyurt, K.T. (2007).Accounting Ethics Education in Turkish Public Universities. Journal of Social Responsibility, 3(4), 74-80. http://dx.doi.org/10.1108/17471110710840251

Callahan, D. (1980). Goals in the teaching of ethics In D. Callahan \& S. Bok (Eds.), Ethics teaching in higher education (pp. 61-80) New York: Plenum Press. http://dx.doi.org/10.1007/978-1-4613-3138-4_2

Carlino, B. (2006). A nexus of vision. Accounting Technology, 22(9), 2. from the Business Source Complete database

Chilton, R. (1992). The American accounting profession and its code of ethics: 1887-1933. Unpublished doctoral dissertation, Boston University, Boston, MA, from ProQuest Dissertations and Theses database

Cohen, J.R., \& Pant L.W. (1989). Accounting Educators' Perceptions of -Ethics in the Curriculum. Journal of Issues in Accounting Education, 4(1), 70-81.

Collins, D., \& Wartick. S. L (1995).Business and Society/ Business Ethics Courses: Twenty 
Years at the Crossroads. Business \& Society, 34(1), 51-89. http://dx.doi.org/10.1177/000765039503400104

Cooke, R. A. (1992). Business ethics: a perspective. Arthur Andersen, Business Ethics Program. Chicago, Illinois.

Cooper, B. J., Leung, P., Dellaportas, S., Jackling, B., \& Wong, G. (2008). Ethics education for accounting students A toolkit approach. Accounting Education: An International Journal, 17(4), 405-430. http://dx.doi.org/10.1080/09639280802436681

Dellaportas, S. (2006). Making a difference with a discrete course on accounting ethics. Journal of Business Ethics, 65, 391-404. http://dx.doi.org/10.1007/s10551-006-0020-7

Duska,R.F., \& Duska,B.S. (2003) Accounting Ethics. Malden, MA: Blackwell Publishing.

Duriau, V.J., Pfarrer, M. D., \& Reger, R. K. (2007). A Content Analysis of the Content Analysis Literature in Organization Studies: Research Themes, Data Sources, and Methodological Refinements. Organization Research Methods, 10, 5-34. http://dx.doi.org/10.1177/1094428106289252

Dyball, M.C., Hazelton, J., Tweedie, D. \& Wright, S. (2012). Teaching Global Ethics Standards: A Case and Strategy for Broadening the Accounting Ethics Curriculum. Journal of Business Ethics, 115(1), 1-15.

Edwards, J., \& Shildneck, B. (1987). The AICPA's first century. Management Accounting, 69(3), 57-61.

Elias, R. (2004) “An examination of business students' perception of corporate social responsibilities before and after bankruptcies" Journal of Business Ethics, 52, 267-281. http://dx.doi.org/10.1023/B:BUSI.0000037558.74693.d5

Emiliani, M.L. (2004).Is management education beneficial to society? Journal of Management Decision, 42(3/4), 481-498.

England, T. (1998). An exploratory study of gaps in selected ethics norms of professional accountants. Dissertation Abstract International, 59(07), 2594a (UMI No.9900127) from ProQuest Dissertations and Theses database

Fleming, A.I.M. (1996). Ethics and Accounting Education in the UK- a Professional Approach? Journal of Accounting Education, 3(1), 207-217. http://dx.doi.org/10.1080/09639289600000021

Gilligan, C. (1977). In a different voice: Women's conceptions of self and of morality. Harvard Educational Review, 77(4), 481-517.

Glenn, J. R. (1992) "Can a business and society course affect the ethical judgment of future managers?” Journal of Business Ethics, 11, 217-223. http://dx.doi.org/10.1007/BF00871969

Gordon, R. A., \& Howell, J. E (1959) Higher education for business. New York: Columbia University Press. 
Gungormus, H.A., \& Uyar, A. (2013). Accounting Professionals' Perceptions of Ethics Education: Evidence from Turkey. Journal of Accounting and Management Information Systems, 12(1), 61-75.

Gunz, S. \& McCutcheon, J. (1998). Are Academics Committed to Accounting Ethics Education?”, Journal of Business Ethics, 17, 1145-1154. http://dx.doi.org/10.1023/A:1005780120229

Guy, D, M., Carmichael, D, R., \& Lach, L. A,(2003). Ethics for CPAs: Meeting expectations in challenging times Hoboken, NJ: John Wiley \& Sons.

Harmon, W, K,. Lambert, K, R \& Rezaea, Z. (2006). Electronic Commerce Education: Analysis of Existing Courses. Accounting Education: an international journal, 15(1), 73-88, March 2006

Hiltebeitel, K. M., \& Jones, S. K. (1991). Initial evidence on the impact of integrating ethics into accounting education. Issues in Accounting Education, 6(2), 262-275.

IFAC International Federation of Accountants (2006). Approaches to the Education development and Maintenance of Professional Values, Ethics in Attitudes in Accounting Programs, Information Paper. New York: International Accounting Education Standards Board

Jennings, M. (2004). Incorporating Ethics and professionalism into accounting education research: A discussion of the voids and advocacy for training in seminal works in the business ethics. Issues in Accounting education, 19(2), 7-26.

Jones, J., Massey, D. W., \& Thorne, L. (2003). Auditors' ethical reasoning: Insights. from past research and implications for the future. Journal of Accounting Literature, 22, 45-103.

Kohlberg, L. (1969). Stages and sequence: the cognitive approach to socialization. Handbook of Socialization and Theory Research, edited by D. Goslin, Chicago: Rand McNally, pp $347-480$

Kohlberg, L. (1973). Continuities in childhood and adult moral development revisited In life-Span Developmental Psychology: Personality and Socialization, edited by P.B.

Kohlberg, L. (1981). The meaning and measurement of moral development (Heinz Werner Lecture Series, Vol. 13) Worcester, MA: Clark University Press.

Kotb, A., \& Roberts, C. (2011). E-business in Accounting Education: A Review of Undergraduate Accounting Degrees in the UK and Ireland. Accounting Education Journal, 20(1), 63-78. http://dx.doi.org/10.1080/09537325.2010.547318

LaGrone, R. M., Welton, R. E., \& Davis, J. R. (1996). Are the effects of accounting ethics interventions transitory or persistent? Journal of Accounting Education, 14(3), 259-276. http://dx.doi.org/10.1016/0748-5751(96)00022-X

Langenderfer, H.Q., \& Rockness, J.W. (1989). Integrating Ethics into the Accounting Curriculum: Issues, Problems, and Solutions. Journal of Issues in Accounting Education, 4, 
$58-70$

Loeb, S. (1988). Teaching students accounting ethics: Some crucial issues. Issues in Accounting Education, 3(2), 316-329.

McMahon, T. F. (1999). A brief history of American business ethics In a companion to business ethics Frederick (Ed.). Malden, Massachusetts: Blackwell Publishers

McPhail, K. (2001). The Other Objectives of Ethics Education: Re-humanizing the Accounting Profession- a Study of Ethics Education in Law, Engineering, Medicine and Accountancy. Journal of Business Ethics, 34(3/4), 279-298. http://dx.doi.org/10.1023/A:1012576631990

Mele, D. (2005). Ethical education in accounting: Integrating rules, values and virtues. Journal of Business Ethics, 57(1), 97-109. http://dx.doi.org/10.1007/s10551-004-3829-y

Misiewicz, K. (2007). The normative impact of CPA firms, professional organizations and state boards on accounting ethics education. Journal of Business Ethics, 70, 5-21

Molyneaux, D. (2004). After Anderson: An experience of integrating ethics into undergraduate accounting education. Journal of Business Ethics, 54, 385-398. http://dx.doi.org/10.1007/s10551-004-1827-8

Oddo, A. R. (1997). A framework for teaching business ethics. Journal of Business Ethics, 16(3), 293-297

Paine, L. S. (1988). Ethics education in American business schools, Washington, DC: Ethics Resource Center, Inc.

Parmental, G. L. (1989). The course in business ethics: can it work? Journal of Business Ethics, 8, 547- 551. http://dx.doi.org/10.1007/BF00382930

Pfarrer, M, D,.Pollock, T, G., \& Rindova,V , P. (2010). A Tale of Two Assets: The Effects of Firm Reputation and Celebrity on Earnings Surprises and Investors Reactions. Academy of Management Journal, 53: pp1131-1152. http://dx.doi.org/10.5465/AMJ.2010.54533222

Pierson, F. C. (1959) The education of American businessmen: a study of university college programs in business administration. New York: McGraw Hill

Piper, T. R., Gentile, M. C., \& Parks, S. D. (1993). Can ethics be taught? Boston: Harvard Business School.

Ponemon, L. A. (1992). Ethical reasoning and selection - Socialization in accounting. Accounting, Organizations and Society, 77(3/4), 239-258. http://dx.doi.org/10.1016/0361-3682(92)90023-L

Powers, C. W., \& Vogel, D. (1980) Ethics in the education of business managers. New York: Hastings-on-Hudson, Institute of Society, Ethics, and the Life Sciences.

Rest, J. R. (1986). Moral Development: Advances in Research and Theory, Praeger, New York 


\section{Macrothink}

Journal of Management Research

ISSN 1941-899X 2015, Vol. 7, No. 2

Royse, D. (2001). Teaching tips for college and university instructors: A practical guide. Boston: Allyn and Bacon

Shannon, J. R., \& Berl, R. L (1997). Are we teaching business ethics in marketing: a survey of students' attitudes and perceptions. Journal of Business Ethics, 16(10), 211-219. http://dx.doi.org/10.1023/A:1017922005651

Shaub, M., \& Brown, J (1992).A case for updating management accountants' ethical Standards. Managerial Auditing Journal, $\quad 7(2), \quad 30-37$. http://dx.doi.org/10.1108/EUM0000000001779

Sims, R. R. (2004). Business ethics teaching: Using conversational learning to build an effective classroom learning environment. Journal of Business Ethics, 49(2), 201-211.

Swanson, D. (2003).Business Ethics Puts Corporate Reputations at Risk. Journal of the Corporate Citizen, 13(4), 68-84.

Thorne, L. (2001). Refocusing ethics education in accounting: An examination of accounting students' tendency to use their cognitive moral capacity. Journal of Accounting Education, 79(2), 103-117. http://dx.doi.org/10.1016/S0748-5751(01)00014-8

Trevino, L. K. (1986). Ethical decision-making in organizations: A person-situation Interactions Model. Academy o $f$ Management Review, 11(3), 601-617. http://dx.doi.org/10.5465/AMR.1986.4306235 